\title{
Improving knowledge on child abandonment and care in Africa: A demographic contribution to the achievement of child protection
}

\author{
Valérie Delaunay \\ Institut de Recherche pour le Développement \\ Laboratoire Population-Environnement-Développement (LPED-UMR151) \\ BP 434 -101 Antananarivo - Madagascar \\ Valerie.Delaunay@ird.fr
}

\section{Abstract}

Carrying out a focused literature review on child abandonment and care in Africa, this paper aims to show that the understanding of this question remains very incomplete, the classification of situations is unsettled and their measurement is lacking in terms of both prevalence and trends. Argumentation is founded on a conceptual framework that gives a central place to the concept of disruption in the process of childcare, and that suggests determinant factors causing disruption and possible responses from families or from institutions.

Some socio-cultural and economic factors highlight disruptions in the process of child care. Responses to these disruptions are largely familial, but also institutional. Some circumstances can lead to abandonment or child endangerment. The anthropology of infancy gives a great deal of information on cultural and social foundations of abandonment and on family systems of child circulation. Child demography remains focused on mortality, nutrition, education and birth registration. Demographic analyses give few answers on disruption in child care. It appears important today to improve data collection in order to better understand I) child status in the family and mechanisms of solidarity that involve children; 2) issues concerning street children and working children; 3) situation of child endangerment outside as well as inside the family. Thus, progress of social science research, particularly in demography, on these issues in Africa would give important results necessary for improving policies regarding child protection.

Keywords : Child abandonment; orphan; infanticide; child care disruption; Africa.

\section{Résumé}

S'appuyant sur une revue de la littérature sur l'abandon et la prise en charge des enfants en Afrique, cet article vise à montrer que cette problématique n'est pas explorée en profondeur, que la diversité des situations est mal connue et que les mesures font défaut, tant en terme de prévalence que de tendance. L'argumentation se base sur un cadre conceptuel qui accorde une place centrale à la rupture de prise en charge de l'enfant. Les déterminants de ces ruptures sont discutés ainsi que les réponses possibles apportées par la famille ou les institutions.

Des facteurs socio-culturels et économiques permettent de comprendre les situations de rupture de prise en charge de l'enfant. Les réponses à ces ruptures 
sont avant tout familiales, mais aussi parfois institutionnelles. Certaines circonstances conduisent à des situations d'abandon ou de mise en danger de l'enfant. L'anthropologie de l'enfance apporte de nombreux éléments sur les fondements culturels de l'abandon et sur les systèmes familiaux de circulation des enfants en Afrique. Les analyses démographiques, quant à elles, sont centrées sur la mortalité, la nutrition, la scolarisation et l'enregistrement des naissances, et apportent peu d'éléments sur les situations de ruptures de prises en charge des enfants. II est nécessaire aujourd'hui d'améliorer la collecte de données pour mieux comprendre I) le statut de l'enfant dans la famille et les mécanismes d'entraide qui impliquent les enfants ; 2) les situations des enfants des rues et des enfants travailleurs ; 3) les situations de mises en danger de l'enfant en dehors comme au sein de la famille. Ainsi, la recherche en science sociale, particulièrement en démographie sur la question de la prise en charge de l'enfant en Afrique apporterait des éléments importants pour l'amélioration des politiques de protection de l'enfant en cours dans ces pays.

Mots clés : Abandon d'enfants; orphelins; infanticide; rupture de prise en charge; Afrique.

\section{Introduction}

Until recent years, child protection in Africa was not a social issue. "There were no formal mechanisms to protect children, but then none would have been necessary. Abundant land, a subsistence economy, and the highly developed sense of generosity due to all family members, underwrote the support obligation" (Bennett 1993: 33). Over the last decades, children's rights issues are increasingly seen to be of international concern. Child protection policy in Africa is today mostly guided by an international agenda referring to the United Nations Convention on the Rights of the Child (1989). This legal setting "asserts a number of rights for children worldwide, sets out basic principles to be applied, and creates a legal obligation to put these rights and principles into practices" (Panter-Brick 2000: 10).

Discourse about childhood has progressed during the twentieth century in developed countries, reflecting the change over time of the value attributed to children in the Western world and the emergence of the concept of 'proper childhood' (Panter-Brick 2000: 4). In Europe, the historian Philippe Ariès' work on representations of childhood have shown how concepts related to childhood have changed from the Middle Ages to the Modern Period (Ariès 1975). The child's specificity socially considered as a miniature adult - was overlooked during the Middle Ages. High child mortality impedes mothers and fathers to provide attentive care to their children. The child's specificity and his or her relevance gradually appear during the Modern Period. Parents' attachment to their children has increased with birth control and fertility decline, along with the downward trend of infant mortality since the end of the eighteenth century. Throughout the nineteenth century, the recognition of the value of the child or childhood has been enhanced in the Western world resulting in the formulation of the first official texts on child 
protection at the onset of the twentieth century (Rollet 1990).

The first Declaration of the Rights of the Child, known as the "Geneva Declaration," was adopted in 1924 by the League of Nations. The Universal Declaration of Human Rights - incorporating specific provisions concerning child protection - was adopted by the General Assembly of the United Nations in 1948. The Declaration of the Rights of the Child, adopted in 1959 by the United Nations, aimed at bringing child-appropriate and child-specific legal protection. Beginning in 1989, African States promised to implement measures to protect children in line with the Convention on the Rights of the Child proposed by the General Assembly of the United Nations. This Convention was followed by the African Charter on the Rights and Welfare of the African Child adopted by the $26^{\text {th }}$ Ordinary Session of the OAU Assembly of Heads of States and Governments held in Addis Ababa in 1990. Throughout this period, political instruments were established, among which the United Nations International Children's Emergency Fund (UNICEF), created in 1976, which has largely contributed in the formulation of texts and international policies, and the Committee on the Rights of the Child, created in 1991, which examines the progress made by the signatory States of the Convention.

Today, all understanding about childhood, particularly in Africa, is strongly determined by the leading international organizations' (United Nations Development Program, World Health Organization, World Bank, UNICEF) view on childhood: an approach based on the concept of "childhood protection". Children are vulnerable and can experience different forms of violence, child abuse, neglect and exploitation. States must protect them. These organizations have agreed to implement effective child protection policies through the ratification of international documents including the Convention on the Rights of the Child (1989). Efforts were carried out by international organizations to produce indicators measuring the level of vulnerability and tracking progress (ODEROI 2006; UNICEF 2003; 2007a; 2007b; 2009). Results are quantitativebased and mostly indicate trends in child survival (mortality levels, probable causes of death, malnutrition, immunization) and education (school enrolment rates).

Although research on child protection has made important progress in developed countries (Leventhal 2003), there are, admittedly, gaps in terms of description, definitions and understanding of the different aspects of child protection in Africa (Lachman 2004). Many of them are unknown. There is little documentation on: I) situations of violence, neglect, child abuse, and abandonment; 2) conditions of childcare including for orphans; and 3) institutional responses. The difficulties in studying these questions partly result from the fact that the perception of child abuse pertains, particularly in Africa, to the private and family sphere (Lachman 1996). Child sexual abuse in Africa is only addressed in some countries (particularly in South Africa) and for specific groups (in particular through clinical cases) (Lalor 2004). The collected data is incomplete and often anecdotal, and is used to justify recom- 
mendations concerning the implementation of child protection policies.

It appears important today to better assess and understand childhood issues. There is a widely recognized need for reliable data and joint definitions and for on-going efforts to strengthen data collection and indicator monitoring, and develop research on child abuse and neglect and on impediments to child protection (Lachman 1996; 2004; UNICEF 2007b).

Given the lack of data, international organizations base their view on the socalled "a priori" approach, based on M. Singleton's expression (Singleton 2004). Knowledge today - anecdotal or based on case studies - is used as a good or bad example in relation to certain ethics or moral codes, blaming or promoting actors and practices, and aimed at protecting vulnerable children. This approach only permits observation of violence in extreme cases and the complexity of situations and behaviors throughout societies and cultures.

How can research contribute in developing elements enabling an $a$ posteriori reflection on childhood protection? The review of available studies in social sciences (Bonnet 1997; Goody 1982; Lachman 1996; 2004; Lallemand 1993; Panter-Brick 2000) has highlighted child care as a central issue within the concept of childhood protection. Whether children are cared for within or outside the family, or by institutions, the disruption - total or partial - leads to children's exploitation, illtreatment, neglect or abandonment. Adversities faced by children worldwide such as poverty, war, family dislocation (death of a parent or divorce), family violence, abandonment and HIV/
AIDS, are related to childcare issues. What happens during a crisis when natural guardians are no longer able to care for the child? What solutions are provided within the family circle? What are the existing family and social controls in the face of family care disruptions that are endangering children? What solutions are suggested by the civil society and the State?

The need for definitions and an explicative framework has never been so urgent. To establish prevention and action policies (expected by international bodies), there is a need: I) to understand child circulation; 2 ) to distinguish placements in the interests of children from processes leading to child exploitation or from social and cultural exclusion; 3) to separate transitional situations - deserving an urgent response - from permanent situations calling for an answer in the long run; finally, 4) to understand cultural foundations of some rejection behaviors.

To synthesize knowledge about childhood, a thorough literature overview of social science studies on African societies was carried out. This review aims at establishing distinctions to better define different behaviors, situations and processes and at building an effective explicative and operational framework. The work of ethnologists on African societies provides a description of cultural representations of childbearing, whose principles organize kinship, gender, status and power relations. The child's position at birth within his or her family and the circumstances of his or her exclusion become very explicit as soon as they are set within representations. The sociology and anthropology of childhood made it possible to high- 
light the plurality of childhood and its social foundations that vary widely throughout the world. The child is not an individual's or a couple's child, but belongs to the lineage, the "extended family" or the "big family" according to the established expressions. Circulation systems within kinship or the social network allow children to be cared for during crises (separation, death, disease, loss of employment, large families) when guardians, more often the biological father or mother, are unable to do so.

The issue of child abandonment and care arises within a social and cultural context characterized on the one hand by representation and norm systems in which rejection behaviors' are meaningful, and on the other hand by child circulation and fostering practices (Lallemand 1993). Admittedly, abandonment can only be understood within its specific cultural, social and historical context (Panter-Brick and Smith 2000). Abandonment takes various forms that can lead to the child's death (infanticide practice), to a growing number of street children (child abuse and neglect) and child domestic workers (exploitation) and can also be connected to child fosterage - temporary or permanent for the child's sake (the giving of a child).

This paper aims to review existing literature on child abandonment and care in Africa and to suggest an operational and explanatory framework. First, we analyze the cultural and social foundations of child abandonment, making it possible to understand rejection practices and question their disappearing and/or current change. Second, we examine child circulation systems that respond to childcare crises. Yet, today these systems display "perverted" forms whose consequences are detrimental for children. Lastly, the concept of childcare is addressed and will be at the core of the designed explanatory framework on childhood protection. Operational proposals have been put forward.

Anthropological, sociological and demographic literature has been consulted. Extensive searches were conducted of all major relevant electronic databases (Jstor, Popline, Sciences Direct, Blackwell) as well as hand searches of selected journals and books.

\section{Cultural and social founda- tions of abandonment}

Infanticide: abandoned practices?

Representation systems of the childbearing process generally confer a lifegiving breath on a spirit or divinity that will thus provide a full-fledged social status for the newborn baby. The naming ceremony is often the landmark of this passage and takes place a certain time after birth. Some "abnormal" births (deformed children, twins, breech birth, etc.) have been subject to infanticide, generally immediately, while the child is "at the doorstep of life". This act is not assimilated to a murder, all the more so since the real being will come back within another body: "Making him die is not elimination but a postponement. He remains an immediate candidate for a coming life" (Erny 1988: 277).

These abnormal children or births

I. Including infanticide. 
are believed to be an evil sign, a curse or witchcraft - a harmful situation for the family and friend circle leading to the death or exposure of the child. The survival of the mother, the parents and even the clan depends on it. These practices meet social obligations involving the whole group; their justification is "an order (both cultural and natural) that must face disorder" (Singleton 2004: 26).

Ethnological studies have described many practices, often from the past, of infanticide or abandonment of children born in "extra-ordinary" circumstances (related to the time of childbirth, the child's position, twinship) or, showing a special feature or a visible handicap (teeth, deformity, albino children). Therefore, some children are suspected to be ghosts: "those who are born to die" (Lolo 199I). In traditional societies of southern Cameroon, "newborn babies, afflicted with an important organic disease, were doomed to death including autistic children" (Lolo, I991). In Benin, deformed children and newborns whose mothers had died in delivery or had an "abnormal" labor (labor dystocia) were victims of infanticide (Agossou 2003; Mattern 2007). Among the Changa in northern Tanzania, infanticide occurred in the case of abnormal births, deformed newborns and twins (Raum 1967; Singleton 2004). In Ghana deformed children born with teeth or born after their mother had a difficult pregnancy are suspected to be spirits. If the spirit is uncovered, he cannot stay in the world. The child must take a poisonous potion. If the child survives, he or she is left in the bush for two nights; if he or she lives through it, the child can again take his or her place (Allotey and Reidpath 200I).

Twins are often subject to specific treatments. Their arrival can be interpreted positively, like among the Kedjom from Cameroon ((Diduk 1993; 200I). However, they have often experienced significant discrimination (Ball and Hill 1996). In the lgbo cultural area located in southeast Nigeria, twins were systematically eliminated since they were considered to be an abomination towards the earth divinity (Achebe 1967). Among the M'bali of Angola, twins were murdered because their birth represented a disaster for the whole country (Erny 1988). Among the Antambahoaka of southeast Madagascar, twins were eliminated through the witch doctor's intervention to protect the children's parents (Van Gennep 1904). Nevertheless, most of these studies mention field observations rather from the past. Renne and Bastian report that ethnologists paid attention to the question of twins in the 1920s, then in the late 1960s and in the 1970s, but there are only a few studies today (Renne and Bastian 200I).

Today, we presume that infanticide practices have ended under the influence of religious missionaries who played a significant role in the break with these ancestral infanticide practices during the colonial period (Bastian 200I). Alternative practices are reported; these intend to make "extraordinary" children and their genitors pay a fine (through dances and ceremonies) to clear them of all suspicion (Singleton 2004). Furthermore, in most countries laws labeling infanticide as a crime were implemented, making it illegal and punishable by law. The establishment of foundling homes for 
disabled children or twins has contributed highly in abating infanticide and exposure practices by providing an acceptable option for parents. Nevertheless, are we really able to say today that infanticide practices have totally disappeared? Moreover, even if these "extraordinary" children are no longer killed, are they still victims of discrimination?

Today children are known to be victims of discrimination, labeled as emotional neglect (Lolo 199I), social neglect (Bonnet 1997) or symbolic abandonment (Ezembé 2003) from their mothers or their social groups complying with some beliefs. Among the lgbos of Nigeria, twin-murder is not socially valued anymore. Nevertheless, behaviors putting physical distance (fosterage of a twin) or social distance (refusal to dress twins identically, twin's birthday not shared) have been observed (Bastian 200I). A recent qualitative study shows that infanticide among the Antambahoaka of Madagascar has shifted into abandonment, by entrusting children either to distant relatives or to shelters established since the late 1980s. Some parents may choose to bring up their twins but then become victims of discrimination (Fernandes 2008).

However, it is still very difficult to define precisely the discriminatory practices (towards children but also towards parents who choose not to respect the ban), to assess them and to ensure an end to infanticide practices. Studies on contemporary infanticide practices are nearly nonexistent. There is a dearth of data and the underreporting of births in the civil registration system does not make it possible to establish a reliable measurement. Nevertheless, one example must be mentioned. In northern Ghana, the Navrongo Demographic Surveillance Site is a study area where accurate and repeated surveys enabled these practices to be uncovered. The analysis of causes of neonatal deaths over a 7-year period (1995-2002) has shown that infanticide accounted for $5 \%$ of all neonatal deaths (Baiden et al. 2006). Although this indicator fails to be produced elsewhere, it would be very useful in guiding action programs. Data registration must be improved in order to develop statistics on the future of these children born in "abnormal" circumstances. This lies in particular on the improvement of vital event registration (birth, death).

\section{Extra marital births: another rejection factor}

European historical demography studies have shown that the stigma of illegitimate birth is one of the main causes of child abandonment between the seventeenth and the twentieth centuries (Fuchs 1992; Morel 2003). Illegitimate children born from single or adulterous mothers are not accepted within families. In the seventeenth century, these births constituted most of the children cared for in foundling homes. In the eighteenth century, the Church introduced a system allowing babies to be abandoned anonymously to preserve the bourgeoisie from the dishonor of out-of-wedlock births. This system is known as foundling wheels; in France they are called "abandonment towers, [which are] revolving hatches with two doors that made it possible to take care of the baby without delay while ignoring the identity of the one who is abandon- 
ing the child" (Morel 2003).

This procedure of anonymity exists in France where mothers can give birth without declaring their identity, known as "childbirth under $X, " 2$ highly questioned by the defenders of the right to know one's origins (Faqué 2004; Guillin 1996; lacub 2003). The introduction of birth control in the mid-twentieth century and the liberalization of abortion across Europe has allowed access to an effective prevention of unwanted births and an equivalent reduction of abandonments. In France, the proportion of children abandoned at birth is estimated at I per 1000 in 1966 (Marinopoulos 1997).

As it was in Europe in the past, sexuality before or outside marriage is often highly stigmatized in Africa. Literature on adulterous births is very scarce for the reason that paternity in Africa is more social than biological, ensured by the dowry payment (Mouvagha-Sow 2006). In consequence, the husband is naturally the father of all births by his wife. Adultery is often seen as a threat to the embryo, provoking abortion because of incompatibility between the husband's and the lover's semen (Hurault 1987). In this circumstance, acknowledged 'adulterous children' are rare. Births from an adulterous liaison are today more visible in the case of a husband's long-term migration. But adultery often takes place inside the family so that the migrant husband is socially constrained to recognize the child (Barou 200I).

On the contrary, literature on pre- marital sexuality and fertility is huge and some of them suggest a relation between premarital fertility and child abandonment. In Cameroon, the growing number of abandoned children is seen as one of the most dramatic signs of socio-economic marginalization among single mothers and their children (Calvès 2006). Children cared for in institutions (day nurseries or orphanages) are often abandoned or entrusted by single mothers. This is particularly the case in Algeria, where a study carried out in the 1980s has shown that abandoned children - whose numbers are growing regularly - were nearly exclusively born from young single mothers (Lacoste-Dujardin 1986). Likewise in Tunisia, the fear of family punishment leads single mothers to commit infanticide or to abandon their children (Lamari and Schlürings 2000; Zemni et al. 2000). A study in Senegal analyzed 33 psychiatric experts' reports on infanticides between 1968 and 1994. Only two cases of mental diseases have been identified. Most of these cases (30 out of 33) concern single or married women whose husbands have migrated (Menick 2000). Another study in Senegal illustrates unfaithfulness as a cause of neo-naticide (Sow et al. 1989). A hospital-based study in Brazzaville mentioned the cases of nine newborns, who had been abandoned and were hospitalized for prematurity or neonatal infection in 1997. All the mothers were young (three-quarters were minors) and seven of them were single (Miakayizila, Ganga-Zandzou and Mayanda

2. "Childbirth under X" is the possibility for a mother to give birth without declaring her identity. In concrete terms, this means that the child is entrusted into care for adoption and will never be able to know the identity of his or her biological mother unless she asks for it. 
2000). A study carried out in Tanzania on 14 indictments for infanticide issued by the Supreme Court of Justice of Dar es Salaam showed that three-quarters of these cases concerned teenagers (Rwebangira 1994). Clearly, the fear of family and social rejection leads young single mothers and some adulterous mothers to resort to the abandonment of newborns or even infanticide.

\section{Family systems of child circulation}

In many African societies, a system exists for giving a child as a gift, thus enabling children to circulate within the extended family since they belong to the lineage rather than to birth parents. The traditional system of child circulation ranges from temporary and not exclusive fosterage to exclusive donation of a child resulting in the child's adoption. Factors leading to child circulation vary from a response to a family crisis (parental death, divorce, migration) to a need for domestic assistance or a lack of children in the case of sterility (Bledsoe 1990; Castle 1995; Goody 1982; Jonckers 1997; Lallemand 1988; 1993; Madhavan 2004; Rabain 1979). These practices aim at creating or strengthening solidarity and kinship relationships. These links are settled within a family and social organization that is guided by a burden-sharing principle applied to the whole family network (Antoine et al. 1995; Marie 1997; Oppong 1999; Pilon and Vignikin 2006).

The giving of a child prevails over child abandonment among the adoption practices described by anthropologists. There is no breaking-off with biological parents even when the giving of the child is exclusive with a total transfer of responsibilities. In Africa, the giving of a child does not "require the establishment of a distance between the giver and the one who adopts, and even less a secret" (Journet 2004). The giving of a child is not shameful and the caregivers are gratified. The giving of the child generally occurs when the child is autonomous and the contact with biological parents is not broken (Ezembé 1997; 2003). Thus, '[....] in Africa, [...], the content of the terms "abandonment" [and] "adoption" has a completely other meaning, for one thing because the child belongs more to the group than to [his or her] birth parents' (Lallemand 1988). Child transfers - temporary or permanent - are common within kinship.

Today growing urbanization and changes of the mode of production modify the social and economic family organization and consequently the place and role of the child within the family. Several studies presented below highlight two aspects: I) Foster care is becoming diversified and crises endangering children (labor, physical or sexual abuse) are appearing; 2 ) The family support system for child members of the lineage - responding to compelling family solidarity - is weakened, nowadays, due to the growing demand and hardships.

\section{New forms of circulation}

The pattern of circulation of children through social exchange tends to diversify. Child transfers are also sometimes motivated by economic reasons. For several decades, schooling access is a cause for entrusting a child to the care of an urban family in exchange of some domestic work (Jacquemin 2002; Jonckers 1997; Vandermeersch 2002). 
Rural poverty also leads families to send their children to seek work in town. This situation tends to be generalized, with a growing number of teenagers, increasingly young, who leave rural areas to seek supplementary income when the agricultural schedule permits it (Delaunay, Adjamagbo and Lalou 2006; Erulkar et al. 2006).

Then, child placement shifts into a kind of service or work (Oppong 1997). Unlike harmonious traditional transfers within kinship, transfers that are nowadays developing under certain constraints may put the child in a situation of high vulnerability or even danger. These children are at risk of different types of discrimination (nutritional, work, violence including sexual abuse). Access to the labor market depends at first on family networks that are getting increasingly structured and organized and in which family control is excluded more and more. The risks of drift are important and these aspects would deserve deeper investigation. Thus, current models of child circulation are related to perverted forms of socially justified models.

Childcare due to family "obligation": have limits been reached?

Family obligations can also impose childcare. A child becoming orphaned is therefore usually fostered by his or her closest kin (Goody 1982; Lallemand 1993).

Nevertheless, in some regions today, the number of orphans is increasing in the context of the HIV/ AIDS epidemic. Families coping with the loss of their most productive members have difficulty taking on additional orphan care giving. First, households must provide care for AIDS-infected adults, resulting in a loss of income. Then, a high fertility level implies that households must take care of many orphans at a time. This system of family support is highly compromised by the HIV epidemic, resulting in growing needs for outside care (Madhavan 2004; Miller et al. 2005; Mishra and Bignami-Van Assche 2008).

Moreover, few studies have focused on the consequences of out-of-wedlock births on families. The care of a foster teenage mother and/or her child will affect the living conditions of the foster family who takes on the extra burden of one or two non-productive persons. In addition, the number of births of single mothers is growing because of marriage delay and the increase of adolescent sexuality (Delaunay and Guillaume 2007). This additional child support may contribute to calling family solidarity for childcare into question.

\section{Child protection's research perspectives}

Actions on child protection in Africa are now largely driven by the United Nations Convention on Child Rights, and governments are often supported in policy implementation by international agencies such as UNICEF. Despite efforts developed by this agency to improve knowledge on child abuse and neglect (UNICEF 2007a; 2009), actions on child protection still need better knowledge and validation tools. A deeper assessment and understanding of basic issues that children are facing appears today as a necessity in order to improve the effectiveness of childhood protection programs (Lachman 2004). In particular, it seems necessary to identify factors that determine 
endangered situations for children and to highlight mechanisms of disruption in childcare. This paper suggests a conceptual and explanatory framework aiming at a comprehensive view of different aspects related to child abuse and neglect. This framework aims to identify progress and further needed efforts.

\section{Conceptual and explanatory}

framework

The analysis of this literature enables the formalization of a conceptual and explanatory framework of child endangerment situations (Figure I). Childcare disruptions can first result from rejection situations - culturally and socially dictated - and then from conditions leading to family breakdown (disease, death, union dissolution) - temporary or permanent. Childcare disruptions may be assessed on an intensity scale (ranging from partial to total) and according to several dimensions (emotional and financial). These disruptions can directly lead to child endangerment (maltreatment, neglect, street life, labor exploitation, sexual abuse, prostitution). Conditions leading to family breakdown and rejection behavior can be related; this link may grow in situations of political, family, social or economical crisis. In other words, cultural foundations may constitute a pretext for abandonment during a crisis.

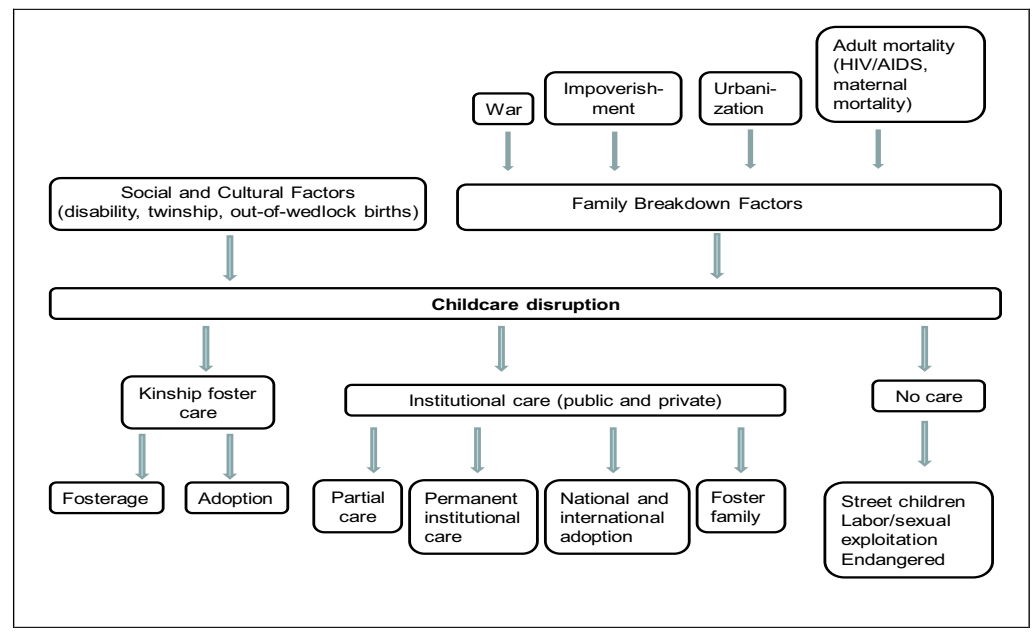

Figure IConceptual and explanatory framework

Nevertheless, some alternative solutions exist. Except in some exceptional cases where the child is considered an evil sign and is rejected by the whole society (Lolo 199I; Singleton 2004; Singleton 2005), an extended family is usually able to take care of children in case of childcare disruption. This fosterage can be permanent and considered an adoption (formal or not). Some fosterage can be more temporary, as for example grandparents' fosterage because of their old age or their scarce resources. So, inside the kinship, we can suppose that child care can be evolving, the child alternatively sup- 
ported by different family members, sharing by that way the burden of an extra-child to feed, clothe and send to school.

Another alternative solution is institutional care, both private and public. This support can be permanent such as long-term placement until adult age or adoption (national or international). It can also be temporary and/or partial: numerous NGOs offer daycare aiming at improving nutritional status and schooling; others offer temporary full time care until reintegration within a family. Except in cases of endangered children, international recommendations today suggest that institutional long-term placement be the last option as a family environment is considered best for the child's well-being (United Nations 2009).

Studies on these issues make it possible to understand some mechanisms, in particular those related to rejection and family breakdown. However, efforts are needed to assess levels and trends. Many questions remain: What are the current forms and intensity of rejection behaviors? In what ways are families changing? Do family structures have an unfavorable impact on childcare?

Management mechanisms of care disruptions are poorly known and deserve an in-depth analysis. Conditions of child placement within the extended family during crisis must be investigated. On the one hand, crisis factors - those that entail family breakdown - seem to be context-based (war, HIV epidemic, impoverishment) and affect the extended as well as the close family. The burdens add up for the most resilient families and the extended fam- ily does not always succeed in meeting these expectations. The child can then experience a new care disruption. On the other hand, solidarities change and respond to a rationality that can lead to selective and self-interested placements - young girls put to work as servants, for example.

Likewise, not all conditions of institutional childcare are known. The lack of public financial and technical means does not allow for coordination of actions for childhood protection - a difficult task due to the growing number of civil society stakeholders. Many research areas need to be investigated, whether they concern children cared for within or outside the family.

\section{Operationalization}

The operationalization of the conceptual and explanatory framework requires different qualitative and quantitative methods to be articulated by analyzing existing data and organizing new data collections. From a quantitative viewpoint, various data can be used. Demographic surveillance systems (DSS) are sources of local but accurate and high quality demographic data (INDEPTH Network 2002). These systems do monitor, more or less longterm, household members, migrations and vital events, and some of them do register changes in marital status and kinship ties between household members (Delaunay et al. 2006). An analysis of this data would be very informative on family breakdown patterns or out of wedlock births and the different subsequent mechanisms of kinship foster care and adoption. Moreover, such sites as Navrongo in Ghana may also help identify infanticide practices (Baiden et al. 2006). Furthermore, these surveil- 
lance systems make it possible to follow up the processes of childcare within families and thus the future of children who are socially and culturally rejected (Adjamagbo, Delaunay and Mondain 2009).

Likewise, national censuses and large-scale surveys, such as the Demographic and Health Surveys (DHS) allow for the analysis of household structures and child placement. These data are nationally representative and can be analyzed to describe differentials and changes in household structures and measure level and trends of fosterage (Vandermeersch 2002).

The biographical approach through the collection of demographic events and life stories can also permit an understanding at the family level of events leading to the child's loss of family protection. At the child level, the biographical approach can permit a description of successive living patterns according to children's family history (Bonvalet and Lelièvre 1995; IPEC 2007; Lelièvre, Bonvalet and Bry 1997).

Lastly, other institutional data (archives, shelter registers) may also be used to sustain these studies. Demographic tools can be applied to identify and characterize child centers, number of children by age and sex, reasons of placement, reasons of exit, and other context data that can help to understand mechanisms of child placement or abandonment. An important question that could be addressed would be to evaluate which children among those in institutions are really abandoned and which are fostered by convenience; in other terms, it could highlight to what extent the existence of child care centers could be the main reason to explain a rise in child placement.

From a qualitative viewpoint, some fields would be "revisited," in particular previously identified situations of child endangerment. In addition, the qualitative approach leads to better understanding of the processes and can articulate with the quantitative approach: downstream from quantitative results to shed light on and illustrate certain results, but can also be upstream for the establishment of quantitative performance tools.

The resources offered by the social sciences of childhood can enable not only understanding of the dynamic of family care systems for children and their instances of disruption, but also the systems of institutional care that have been organized in response (State, civil society) and therefore fully participate in the development of public policies and development actions.

\section{Discussion}

This article has aimed to formulate a review of knowledge on child abandonment and care in the African context and to propose an explanatory and operational framework. The overall finding is that, even though the sociology and anthropology of childhood provides a qualitative insight into various patterns - both past and present - of childcare in Africa, understanding remains quite compartmentalized, the classification of situations remains unsettled and the quantification of various phenomena is lacking, in terms of both prevalence and trends.

However, the legal context has increasingly required that issues of abandonment, maltreatment and situations of child endangerment be consid- 
ered in actions for child protection. The context of international adoption that involves many countries has further reinforced this need. The Convention on the Rights of the Child, proposed in 1989 , has been ratified by all the countries (193 States) including those in Africa. Confronted by identified situations concerning "child victims," such as child soldiers and child prostitution or trafficking, optional protocols have been proposed. ${ }^{3}$ The Committee on the Rights of the Child established in 1991 is the organ in charge of overseeing that the States meet the contracted obligations related to the Convention on the Rights of the Child. Each State must produce an initial report two years following ratification of the convention, then a report every five years. These reports are examined and followed by "observations." The Committee on the Rights of the Child emphasizes the need for the States Parties to organize systematic monitoring of implementation of children's rights by establishing appropriate indicators and collecting sufficient and reliable data
(United Nations 2008).

Nevertheless, few findings have been produced and understanding of the issue remains little more than approximate descriptions of the situations and measurements of their prevalence levels, trends, causes and consequences. Only an increase in the number of journalistic testimonies ${ }^{4}$ and visible increase of stakeholders in the field of child protection (international agencies, NGOs) ${ }^{5}$ reflect the diversity and complexity of the situations that arise.

The demographical void concerning the situation of children's care is meaningful. The lack of statistics on the prevalence, trends and causes of the various types of child transfers, abandonments and rejections is particularly striking. Nevertheless, disruptions in children's care are quite real. The main causes of these disruptions are probably still poverty and the social and cultural stigmatization of certain types of births ("extraordinary" births, illegitimate births). Confronted with ever-present, if not increasing, poverty in Africa, the

3. On I February 2008, on the closing day of the eighty-seventh session of the Committee on the Rights of the Child, 193 States Parties signed the Convention on the Rights of the Child. An updated list of the States that have signed the Convention or that have deposited instruments of ratification or accession can be consulted on the following sites: www.ohchr.org or http://untreaty.un.org. On the same date, II 9 States Parties ratified or acceded to the Optional Protocol to the Convention on the Rights of the Child on the involvement of children in armed conflict and I 22 States have signed. Also, on the same date, 124 States Parties have ratified or acceded to the Optional Protocol to the Convention on the Rights of the Child on the Sale of Children, Child Prostitution and Child Pornography and II 5 States have signed. The updated list of States that have signed the two Optional Protocols or have deposited an instrument of ratification or accession can be consulted on the website www.ohchr.org. United Nations. 2008. "Report of the Committee on the Rights of the Child. General Assembly. Official Documents. Sixtythird Session." New York: United Nations.

4. In urban areas, the cases of newborns found in public places, as underscored by the press, and street children are increasingly visible.

5. Increases in the number of orphanages predominantly established through religious or charitable initiatives bear witness to the fact that children find themselves in situations of abandonment and great vulnerability. 
increase in unwanted pregnancies and births (Bearinger et al. 2007; Bledsoe and Cohen 1993; Brown et al. 200I; Delaunay and Guillaume 2007; Meekers 1994; Singh 1998; WHO 2007), the continued difficulty in accessing abortion (Guillaume and Molmy 2003) and the excessive high rates of maternal mortality (UNICEF 2009), it could be thought that the number of abandonments tends to increase. Added to this situation is the rising number of AIDS orphans and the issue of their care, further supporting this hypothesis. Unquestionably, children's care continues to be a current issue that, from a two-sided perspective, simultaneously reaches across human rights and public health.

Until now, questions related to child neglect addressed in African population studies have focused on mortality (Adetunji 2000; Ahmad, Lopez and Inoue 2000; Baiden et al. 2006; Etard et al. 2004; Rutstein 2000), nutrition (Simondon et al. 2003; Smith et al. 2003), birth registration (Unicef 1998) and education (Lloyd and Blanc 1996; Pilon and Yaro 200I). The main sources of data are Demographic and Health Surveys that produce standardized indicators allowing comparative studies on these issues (Heaton et al. 2005; Tabutin and Schoumaker 2004; Wilcox et al. 2009). Orphanhood is becoming of interest in the context of the AIDS epidemic (Audemard, Vignikin and Desgrées du Loû 2006; Monasch and Boerma 2004). Other new fields of research have appeared and need more in-depth studies. The role of family structure or the child's status on child well-being has been addressed by some authors (Castle 1995; Gage 1997; Gyimah 2009) as, more recently; the role of grandparents (Aubel, Touré and Diagne in press; Zimmer and Dayton 2005). But some essential indicators are still missing. First, some issues are under-researched. This applies to street children, belonging to the category used by UNICEF 'children in especially difficult circumstances' (Black 1996), who are excluded in the DHS sample, because this survey is drawn on households' base. In the same category, despite recent efforts to estimate their prevalence $^{6}$, working children remain underdeclared in surveys, in particular domestic children who are well known as prevalent in Africa (Delaunay and Enel 2009; Destremau and Lautier 2002; Jacquemin 2002). Second, if some children are in any situation of abandonment outside family, a large part of the others live with their kin and familial solidarity allows them (more or less) to confront crisis situations. These processes should also be documented and better understood, in particular situations that put children in any danger, even inside the family (i.e. neglected, exposed to work exploitation or sexual abuse). Third, institutional care should be analyzed, in terms of supply and demand (in particular, how supply can generate demand). Motivation for and causes of child placement need more attention and work should be done to identify conditions of return to a familial environment.

Therefore, the development of research in social and legal sciences on these issues seems necessary for policy

6. International Program on the Elimination of Child Labour of the International Labor Organization is particularly active in producing general statistics on working children. 
breakthroughs in child protection. It is important to improve data collection in order to produce a better description and understanding of the recent changes. Strategies for children's care that have been developed by today's various coexisting family models (extended family, nuclear family, singleparent family, etc.) and instances of disruption leading children into situations of great vulnerability and exploitation should be explored immediately (Ayuku et al. 2003)

\section{References}

Achebe, C. 1967. Le monde s'effondre. [Publisher?] Paris.

Adetunji, J. 2000. "Trends in under-5 mortality rates and the HIV/AIDS epidemic". Bulletin of the World Organization 78, (10): 1200-1206.

Adjamagbo, A., Delaunay, V. and Mondain, N. 2009. "Maternité prénuptiale en milieu rural Sénégalais. Quelles consé-quences pour les enfants ?" pp. 232-235. In Mémoires et démographie : Regards croisés au Sud et au Nord Edited by R. Marcoux and J. Dion. Presses de l'Université Laval.

Agossou, T., ed. 2003. Regard d'Afrique sur la maltraitance. Paris: Karthala.

Ahmad, O.B., Lopez, A.D. and Inoue, M. 2000. "The decline of child mortality: a reappraisal". Bulletin of the World Organization 78, (I0): II75-II9I.

Allotey, P. and Reidpath, D. $200 \mathrm{I}$. "Establishing the causes of childhood mortality in Ghana: the 'spirit child"'. Social Science \& Medicine 52, (7): 1007-1012.

Antoine, P., Bocquier, P., Fall, A., Guisse, Y. and Nanitelamio, J. 1995. Les familles Dakaroise face à la crise. Dakar: IFAN, ORSTOM, Ceped.

Ariès, P. 1975. L'enfant et la famille sous l'ancien régime. Paris: Points Histoire.

Aubel, J., Touré, I. and Diagne, M. in press. "Senegalese grandmothers promote improved maternal and child nutrition practices: the guardians of tradition are not averse to change". Social Science \& Medicine.

Audemard, C., Vignikin, K. and Desgrées Du Loû, A. 2006. Orphans and vulnerable children due to Aids in Africa. Paris: Ceped.

Ayuku, D., Odero, W., Kaplan, C., De Bruyn, R. and De Vries, M. 2003. Social network analysis for health and social interventions among Kenyan scavenging street children. pp. 109II8.

Baiden, F., Hodgson, A., Adjuik, M., Adongo, P., Ayaga, B. and Binka, F. 2006. "Trend and causes of neonatal mortality in the Kassena-Nankana district of northern Ghana, 19952002". Tropical Medicine And International Health II, (4): 532-539.

Ball, $\mathrm{H}$. and Hill, C. 1996. "Reevaluating "Twin Infanticide"'". Current Anthropology 37, (5): 856-863.

Barou, J. 200I. "La famille à distance. Nouvelles stratégies familiales chez les immigrés d'Afrique Sahélienne". Hommes \& Migration 1232: 16-25.

Bastian, M.L. 200I. "'"The Demon Superstition": Abominable Twins and Mission Culture in Onitsha History". Ethnology 40, (I): 13-27.

Bearinger, L.H., Sieving, R.E., Ferguson, J. and Sharma, V. 2007. "Adolescent health 2 - Global perspectives on the sexual and reproductive health of 
adolescents: patterns, prevention, and potential". Lancet 369, (9568): |220-|23|.

Bennett, T. 1993. "Human rights and the African cultural tradition". Transformation 22: 30-40.

Black, M. 1996. Children first: The story of UNICEF, Past and Present. Oxford: Oxford University Press.

Bledsoe, C. 1990. "The politics of children: fosterage and the social management of fertility among the Mende of Sierra Leone". pp. 8I-I00. In Births and power: social change and the politics of reproduction, Edited by W. Handwerker. San Francisco, Westview Press.

Bledsoe, C. and Cohen, B., eds. 1993. Social dynamics of adolescent fertility in sub-Saharan Africa. Washington: National Academy Press.

Bonnet, D. 1997. "'Autorisés à mourir" ou la notion de "Négligence sociale" : le cas de l'enfant malnutri en Afrique de l'Ouest". Cahier de Marjuvia 4: 4349.

Bonvalet, C. and Lelièvre, E. 1995. "Du concept de ménage à celui de l'entrourage : une redéfinition de l'espace familial". Sociologie et Sociétés 2: 177-190.

Brown, A., Jejeebhoy, S., Shahi, I. and Tount, K. 200I. Sexual relations among young people in developing countries: evidence from WHO case studies. Genève: WHO: $50+$ annexes $p$.

Calvès, A. 2006. "Nouveau contexte familial à la naissance, reconnaissance paternelle et prise en charge des jeunes enfants à Yaoundé". pp. 10I-II2. In Enfants d'aujourd'hui. Diversité des contextes, pluralité des parcours, Edited by
Aidelf. AIDELF/INED.

Castle, S.E. 1995. "Child fostering and children's nutritional outcomes in rural Mali: the role of female status in directing child transfers". Social Science \& Medicine 40, (5): 679-693.

Delaunay, V., Adjamagbo, A. and Lalou, R. 2006. "Questionner la transition de la fécondité en milieu rural africain : les apports d'une démarche longitudinale et institutionnelle". Cahiers Québécois de Démographie 35, (I): 27-50.

Delaunay, V. and Enel, C. 2009. "Les migrations saisonnières féminines :le cas des jeunes bonnes à Dakar". pp. 389-40I. In Du genre et de l'Afrique. Ouvrage en hommage à Thérèse Locoh, Edited by J. Vallin. Paris, INED.

Delaunay, V. and Guillaume, A. 2007. "Sexualité et mode de contrôle de la fécondité chez les jeunes en Afrique sub-Saharienne". pp. 215-267. In Santé de la reproduction et fécondité dans les pays du Sud. Nouveaux contextes et nouveaux comportements, Edited by A. Adjamagbo, P. Msellati and P. Vimard. Louvain-la-Neuve, AcademiaBruylant.

Delaunay, V., Guyavarch, E., Arduin, P., Laurent, R., Marra, A., Duthé, G., Kante, M. and Pison, G. 2006. "Les systèmes de suivi démographique : l'intérêt d'une approche comparative". Paper presented for: Chaire Quételet "Les systèmes d'information en démographie et en sciences sociales", Louvain-la Neuve.

Destremau, B. and Lautier, B. 2002. "Femmes en domesticité. Les domestiques du Sud, au Nord et au 
Sud". Tiers-Monde 43, (I70): 249264.

Diduk, S. 1993. "Twins, Ancestors and Socio-Economic Change in Kedjom Society". Man 28, (3): 55I-57I.

Diduk, S. 200I. "Twinship and Juvenile Power: The Ordinariness of the Extraordinary". Ethnology 40, (I): 29-43.

Erny, P. 1988. Les premiers pas dans la vie d'un enfant d'Afrique Noire. Paris: L'Harmattan.

Erulkar, A., Mekbib, T.-A., Simie, N. and Gulema, T. 2006. "Migration and Vulnerability among Adolescents in Slum Areas of Addis Ababa, Ethiopia". Journal of Youth Studies 9, (3): $36 \mathrm{I}-374$.

Etard, J., Le Hesran, J., Diallo, A., Diallo, J., Ndiaye, J. and Delaunay, V. 2004. "Childhood mortality and probable causes of death using verbal autopsy in Niakhar, Senegal, 1989-2000". International Journal of Epidemiology 33: I 286-I 292.

Ezembé, F. 1997. "Circulation des enfants en Afrique : d'hier à aujourd'hui". Journal des Psychologues I53: 48-53.

Ezembé, F. 2003. "Don et abandon des enfants en Afrique". pp. 225-246. In Le bébé face à l'abandon, le bébé face à l'adoption, Edited by M. Szejer. Paris, Albin Michel.

Faqué, P. 2004. Né sous $X$ : Enquête sur I'abandon Paris: Editions Carnot.

Fernandes, G. 2008. "Twin children in Mananjary, Madagascar". Paper presented for: 34th Biennal Congress of the International Association of Schools of Social Work "Transcending Global-Local Divides", Durban. 20-24 july 2008.

Fuchs, R. 1992. "Child abandonment in
European History". Journal of family history 17: 7-13.

Gage, A.J. 1997. "Familial and socioeconomic influences on children's well-being: An examination of preschool children in Kenya". Social Science \& Medicine 45, (I2): 1811 .

Goody, E. 1982. Parenthood and social reproduction. Fostering and Occupational Roles in West Africa. Cambridge: Cambridge University Press.

Guillaume, A. and Molmy, W. 2003. L'avortement en Afrique : une revue de la littérature des années 1990 à nos jours. Ceped.

Guillin, J. 1996. De l'oubli à la mémoire : un autre regard sur l'abandon. Lyon: Editions Xavier Lejeune.

Gyimah, S.O. 2009. "Polygynous marital structure and child survivorship in sub-Saharan Africa: Some empirical evidence from Ghana". Social Science \& Medicine 68, (2): 334-342.

Heaton, T.B., Forste, R., Hoffmann, J.P. and Flake, D. 2005. "Cross-national variation in family influences on child health". Social Science \& Medicine 60, (I): 97-108.

Hurault, J. 1987. "Un ouvrage méconnu : Infécondité en Afrique Noire d'Anne Retel-Laurentin ". Cahiers d'études africaines 27, (105-106): I77-I85.

lacub, M. 2003. "Pour X. L'inconvénient d'être né de personne". Raisons Politiques 12: 55-76.

Indepth Network 2002. Population, Health and Survival at INDEPTH SItes. Ottawa: IDCR.

Ipec 2007. Les déterminants du travail et de la scolarisation des enfants: les enseignements des enquêtes 
biographiques du Burkina Faso et du Mali. Genève: Bureau Internaitonal du Travail: $39 \mathrm{p}$.

Jacquemin, M. 2002. "Travail domestique et travail des enfants, le cas d'Abidjan". Tiers-Monde 43, (170): 307-326.

Jonckers, D. 1997. "Les enfants confiés". pp. 193-208. In Ménages et familles en Afrique. Approche des dynamiques contemporaines, Edited by M. Pilon, T. Locoh, E. Vignikin and P. Vimard. Paris, Ceped.

Journet, N. 2004. "De l'abandon au don: l'adoption dans le monde". Sciences Humaines Hors série 45 "L'enfant": 64-67.

Lachman, P. 1996. "Child protection in Africa - The road ahead". Child Abuse \& Neglect 20, (7): 543-547.

Lachman, P. 2004. "Understanding the current position of research in Africa as the foundation for child protection programs". Child Abuse \& Neglect 28, (8): 8I3-8I5.

Lacoste-Dujardin, C. 1986. "Au Maghreb, l'enfance innomable". Autrement (Abandon et Adoption) 96: 85-90.

Lallemand, S. 1988. "Un bien qui circule beaucoup". Autrement (Abandon et Adoption) 96: 128-134.

Lallemand, S. 1993. La circulation des enfants en société traditionnelle. Prêt, don, échange. Paris: L'Harmattan.

Lalor, K. 2004. "Child sexual abuse in Sub-Saharan Africa: a literature review". Child Abuse \& Neglect 28, (4): 439-460.

Lamari, M. and Schlürings, H. 2000. Forces féminines et dynamiques rurales en Tunisie. Paris: L'Harmattan.

Lelièvre, E., Bonvalet, C. and Bry, X. 1997. "Analyse biographique des groupes. Les avancées d'une recherche en cours". Population 52, (4): 803-830.

Leventhal, J. 2003. "The field of child maltreatment enters its fifth decade". Child Abuse and Neglect 27, (I): I-4.

Lloyd, C.B. and Blanc, A.K. 1996. "Children's Schooling in sub-Saharan Africa: The Role of Fathers, \# Mothers, and Others". Population and development review 22, (2): 265298.

Lolo, B. 199I. "La dyade de la relation mère-enfant ou la prise en charge de l'enfant africain". Transitions 31.

Madhavan, S. 2004. "Fosterage patterns in the age of AIDS: continuity and change". Social Science \& Medicine 58, (7): 1443-1454.

Marie, A. 1997. "Les structures familiales à l'épreuve de l'individualisation". pp. 279-300. In Ménages et familles en Afrique, Edited by M. Pilon, T. Locoh, K. Vignikin and P. Vimard. Paris, Ceped.

Marinopoulos, S. 1997. "Avant l'adoption : l'abandon". Journal des Psychologues 153: 23-26.

Mattern, C. 2007. Etude de la pratique contumière d'infanticide et de rejet des enfants sorciers au sein de l'ethnie baribara du Nord Bénin. In Département des Sciences Politiques et Sociales p. I I 2. Louvain-laNeuve: Université Catholique de Louvain.

Meekers, D. 1994. "Sexual initiation and premarital chilbearing in SubSaharan Africa". Population Studies 48, (I): 47-64.

Menick, D.M. 2000. "Les contours psychosociaux de l'infanticide en Afrique noire: le cas du Sénégal". 
Child Abuse \& Neglect 24, (12): I557-I565.

Miakayizila, P., Ganga-Zandzou, P. and Mayanda, H. 2000. "L'abandon du nouveau-né à la naissance à Brazzaville". Médecine d'Afrique Noire 47, (3): I45-I 48.

Miller, C., Gruskin, S., Subramanian, S., Rajaraman, D. and Heymann, S. 2005. "Orphan care in Botswana's working households: growing responsabilities in the absence of adequate support". American Journal of Public Health 96, (8): I429-I 435.

Mishra, V. and Bignami-Van Assche, S. 2008. Orphans and vulnerable childrenin high HIV-prevalence countries in sub-saharan Africa. 15, Calverton, Maryland: Macro International Inc.: 92 p.

Monasch, R. and Boerma, J.T. 2004. Orphanhood and childcare patterns in sub-Saharan Africa: an analysis of national surveys from 40 countries. pp. S55-S65.

Morel, M. 2003. "Les enfants abandonnés dans la France ancienne (XVle-XIXe siècle)". pp. 19-45. In Le bébé face à l'abandon, le bébé face à l'adoption, Edited by M. Szejer. Paris, Albin Michel.

Mouvagha-Sow, M. 2006. "L'implication des pères dans l'éducation des enfants au Gabon ". Pp. 204-219. In Proceedings of the Conference on Enfants d'aujourd'hui. Diversité des contextes, pluralité des parcours, Paris. AIDELF.

Oderoi 2006. La violence contre les enfants dans la région de l'Océan Indien. Rapport annuel de l'Observatoire des Droits de l'Enfant dans le Région de l'Océan Indien. Maurice: ODEROI: $169 \mathrm{p}$.
Oppong, C. 1997. "African family systems and socio-economic crisis". pp. 158-I82. In Family, Population and Development in Africa, Edited by A. Adepodju. London, England Zed Book.

Oppong, C. 1999. "Les systèmes familiaux et la crise économique". pp. 22I-254. In La famille africaine. Politique démographiques et développement, Edited by $\mathrm{A}$. Adepodju. Paris, Karthala.

Panter-Brick, C. 2000. "Nobody's children? A reconsideration of child abandonment". pp. I-26. In Abandoned children, Edited by $C$. Panter-Brick and M. Smith. Cambridge, Cambridge University Press.

Panter-Brick, C. and Smith, M., eds. 2000. Abandoned children. Cambridge University Press.

Pilon, M. and Vignikin, K. 2006. Ménages et familles en Afrique subsaharienne. Paris: Editions des archives contemporaines/AUF.

Pilon, M. and Yaro, Y., eds. 200I. La demande d'éducation en Afrique : état des connaissances et perspectives de recherches. Dakar: UAPS.

Rabain, J. 1979. L'enfant du lignage. Du sevrage à la classe d'âge chez les Wolof du Sénégal. Paris: Payot.

Raum, O. 1967. Chaga Childhood. Oxford: Oxford University Press.

Renne, E.P. and Bastian, M.L. 200I. "Reviewing Twinship in Africa". Ethnology 40, (I): I-II.

Rollet, C. 1990. La politique à l'égard de la petite enfance sous la III $^{\mathrm{e}}$ République. Paris: INED.

Rutstein, S.O. 2000. "Factors associated with trends in infant and child mortality in developing countries 
during the 1990s". Bulletin of the World Organization 78, (10): 12561270.

Rwebangira, M. 1994. "What has the law got to do with it ?" pp. 187-2I5. In Chelewa, Chelewa. The dilemna of teenage girls, Edited by Z. TumboMasobo and R. Liljeström. Östersund, The Scandinavian Institut of African Studies.

Simondon, K.B., Delaunay, V., Diallo, A., Elguerro, E. and Simondon, F. 2003. "Lactational amenorrhea is associated with child age at the time of introduction of complementary food : A prospective cohort study in rural Senegal, west Africa". American Journal of Clinical Nutrition 78: 154161 .

Singh, S. 1998. "Adolescent childbearing in developing countries: a global review". Studies in Family Planning 29, (2): I I7-136.

Singleton, M. 2004. "Infanticide. Notes de lectures anthropologique à usage éthique". Documents de travail du SPED, UCL Louvain-la-Neuve 20: 48.

Singleton, M. 2005. "Ancestral practices and demography of precolonial Black Africa". Anthropos I00, (I): 5372.

Smith, L., Ramakrishnan, U., Ndiaye, A., Haddad, L. and Martorell, R. 2003. The importance of women's status for child nutrition in Africa. Research Report, 3, Washigton, DC: IFPRI: $164 \mathrm{p}$.

Sow, M., Moreau, J., Mbaye, I., Ndiaye, P. and Benais, J. 1989. "Neonaticides au Sénégal: aspects sociologiques et médico-légaux". Acta Medicinae Legalis et Socialis 39, (2): 277-283.

Tabutin, D. and Schoumaker, B. 2004. "La démographie de l'Afrique au sud du Sahara des années 1950 aux années 2000 : synthèse des changements et bilan statistique ". Population 59, (3-4): 52I-62।.

Unicef 1998. "UNICEF on deficient birth registration in developing countries". Population and Development Review 24, (3): 659-664.

Unicef 2003. Building a World Fit for Children. New York: UNICEF: 24 p.

Unicef 2007a. Progress for Children: A World Fit for Children Statistical Review 6, New York: UNICEF: 68 p.

Unicef 2007b. The State of the World's Children 2008: Child Survival. New York: UNICEF: I54 p.

Unicef 2009. The State of the World's Children 2009: Maternal and Newborn Health New York: UNICEF: $158 \mathrm{p}$.

United Nations 2008. Report of the Committee on the Rights of the Child. General Assembly. Sixty third session (Suppl. 4I). Supplément no 4I (A/ 63/4I), New York: United Nations p.

United Nations 2009. Guidelines for the Alternative Care of Children. A/C.3/ 64/L.50: General Assembly - A/C.3/ 64/L.50: 24 p.

Van Gennep, A. 1904. Tabou et totétisme à Madagascar. Paris: Leroux.

Vandermeersch, C. 2002. "Child Fostering under Six in Senegal in 1992-1993". Population 57, (4-5): 659-685.

Who 2007. Adolescent pregnancy Unmet needs and undoned deeds. A review of the literature and programs.: $99 \mathrm{p}$.

Wilcox, W., Lippman, L., Whitney, C. and Cid, A. 2009. "Making the grade : family structure and children's 
education participation in Colombia, Egypt, India, Kenya, Peru and Uruguay". Paper presented for: XXVle Congrès International de la Population, Marrakech, Maroc.

Zemni, M., Ben Abdallah, E., Ben Dhiab, M., Souguir, M. and Chebaane, N. 2000. "L'infanticide dans le centre tunisien: étude médico-légale et sociale: a propos de 42 cas". Jounral de médecine légale droit médical 43, (7-8): 579-582.

Zimmer, Z. and Dayton, J. 2005. "Older Adults in Sub-Saharan Africa Living with Children and Grandchildren". Population Studies 59, (3): 295-3 I 2. 